\title{
Comparisons of biochemical parameters and diabetic ketoacidosis severity in adult patients with type 1 and type 2 diabetes
}

\author{
Atchara Charoenpiriya ${ }^{1}$, Laor Chailurkit ${ }^{2}$ and Boonsong Ongphiphadhanakul2 ${ }^{*}$
}

\begin{abstract}
Objective: The aim of this study was to determine the differences in biochemical parameters and diabetic ketoacidosis (DKA) severity in adult patients with type 1 and type 2 diabetes and utilization of serum BHB as a biomarker for DKA resolution was also evaluated.

Materials and methods: This prospective observational study of type 1 or type 2 diabetes mellitus who were diagnosed with DKA between 01 October 2018 and 30 September 2020. The correlations between serum BHB, measured by the Ranbut assay, and pH, bicarbonate, and anion gap were examined.

Results: A total of 99 diabetes patients were diagnosed with DKA (mean age 39.4 years, $63.4 \%$ female, 53.6\% T2DM). while infection was the most common precipitating factor in T2DM (43.4\%), non-compliance with treatment was the most common precipitating factor in T1DM (43.5\%). T1DM patients had more severe DKA more hypokalemia during treatment. However, there was no significant difference in mortality between type 1 and type2 diabetes. The initial laboratories evaluation of patients did not significant differ between type1 and type2 diabetes. Serum BHB during treatment of DKA was significantly correlated with changes in serum bicarbonate $(r=-0.64)$, serum anion gap $(r=0.84)$, and venous $\mathrm{pH}(r=-0.6)$. The serum BHB levels corresponding to $\mathrm{HCO}_{3}$ levels for DKA severity were $4.5,5.7$, and $5.9 \mathrm{mmol} / \mathrm{L}$ in mild, moderate, and severe DKA, respectively. The serum $\mathrm{BHB}$ level of $<1$ $\mathrm{mmol} / \mathrm{L}$ had $73.7 \%$ sensitivity and $100 \%$ specificity to predict DKA resolution. Median time to resolution of DKA was $12 \mathrm{~h}$ with an optimized BHB cut-off value of $<1 \mathrm{mmol} / \mathrm{L}$. There were no significant difference in time to resolution of DKA in the patients with type 1 and type 2 diabetes.
\end{abstract}

Conclusions: There are no differences in DKA-related biochemical parameters between type 1 and type 2 diabetes patients. The present findings suggest that DKA should be assessed and treated similarly, regardless of its occurrence in type 1 or type 2 diabetes patients.

Keywords: Beta-hydroxybutyrate, Diabetic ketoacidosis, Type 1 diabetes, Type 2 diabetes

\section{Introduction}

Diabetic ketoacidosis (DKA) is a life-threatening acute complication of diabetes mellitus characterized by hyperglycemia and ketoacidosis. It can occur in both

\footnotetext{
* Correspondence: boonsong.ong@mahidol.ac.th

${ }^{2}$ Division of Endocrinology and Metabolism, Department of Medicine, Faculty

of Medicine, Ramathibodi Hospital, Mahidol University, Bangkok 10400, Thailand

Full list of author information is available at the end of the article
}

type 1 diabetes and type 2 diabetes patients under stress conditions such as infection, surgery, and trauma or under administration of SGLT2 inhibitors. The mortality rate for patients with DKA is about $1 \%$ and the rate rises to $5 \%$ in elderly patients $[1,2]$. Multiple studies of DKA have been carried out in Caucasian populations mainly with type1 diabetes. However, a significant proportion of DKA in Asian populations occurs in type 2 diabetes [3-

C C The Author(s). 2021 Open Access This article is licensed under a Creative Commons Attribution 4.0 International License, which permits use, sharing, adaptation, distribution and reproduction in any medium or format, as long as you give appropriate credit to the original author(s) and the source, provide a link to the Creative Commons licence, and indicate if changes were made. The images or other third party material in this article are included in the article's Creative Commons licence, unless indicated otherwise in a credit line to the material. If material is not included in the article's Creative Commons licence and your intended use is not permitted by statutory regulation or exceeds the permitted use, you will need to obtain permission directly from the copyright holder. To view a copy of this licence, visit http://creativecommons.org/licenses/by/4.0/ The Creative Commons Public Domain Dedication waiver (http://creativecommons.org/publicdomain/zero/1.0/) applies to the data made available in this article, unless otherwise stated in a credit line to the data. 
6] and it is unclear if clinical courses of DKA of type 1 and type 2 diabetes in Asian population differ.

The severity of DKA is generally classified as mild, moderate, or severe according to the American Diabetes Association. However, variations in the criteria exist among different professional societies. It should be noted that the severity criteria for DKA were mainly derived in Western countries, and that it remains unclear whether the criteria are appropriate for Asian populations and whether the severity of DKA is associated with clinical characteristics, biochemical derangements, and outcomes in Asian populations. Furthermore, it is currently unknown whether the severity of DKA based on clinical and biochemical parameters differs in patients with type 1 and type 2 diabetes.

Laboratory findings in DKA consist of hyperglycemia (>250 mg/dL), high anion gap metabolic acidosis, and detection of serum ketone or urine ketone bodies [7]. Three types of ketone bodies, acetoacetate, betahydroxybutyrate $(\mathrm{BHB})$, and acetone, are produced in DKA. The ratio of BHB to acetoacetate in patients with DKA is increased by 10 times compared with the healthy population [8]. The nitroprusside test, which is widely used to assess ketosis, can provide a high false-negative rate in DKA because nitroprusside reacts with acetoacetate and acetone, but not with BHB [9]. Recently, the nitroprusside test has been replaced by direct measurement of serum BHB. The serum BHB cut-off point of $3 \mathrm{mmol} / \mathrm{L}$ in diagnosis of DKA provides 90 $100 \%$ sensitivity and $86-100 \%$ specificity [10-15]. However, the cutoff point of BHB in resolution of DKA remains unclear. The purpose of the present study was to determine the clinical and biochemical features and severity of DKA in Thai adult patients with type 1 and type 2 diabetes and utilization of serum BHB as a biomarker for DKA resolution was also evaluated.

\section{Materials and methods}

This prospective observational study recruited all 99 patients with type 1 or type 2 diabetes mellitus who were diagnosed with DKA between 01 October 2018 and 30 September 2020 at our hospital.

\section{Study subjects}

Patients were assigned to the type 2 diabetes group if they were previously diagnosed and managed with diet and exercise alone or with oral hypoglycemic agents or with insulin but not on a regular basis. Patients with DKA whose medical records indicating prior diagnosis of type 1 diabetes or if serum C peptide was below $1 \mathrm{ng} /$ $\mathrm{mL}$ and received regular insulin treatment at follow-up were regarded as type 1 diabetes. Patients with newly diagnosed diabetes were classified as type 1 diabetes if the level of $\mathrm{C}$ peptide below $1 \mathrm{ng} / \mathrm{mL}$ after resolution of DKA for 4 weeks.

The inclusion criteria were: age $>18$ years, diagnosed with DKA and admitted to Maharaj Nakorn Si Thammarat Hospital, serum blood glucose $\geq 250 \mathrm{mg} / \mathrm{dL}$ and serum $\mathrm{BHB} \geq 3 \mathrm{mmol} / \mathrm{L}$, and venous blood $\mathrm{pH}<7.3$ or serum bicarbonate $<18 \mathrm{mmol} / \mathrm{L}$ [11]. We classified the severity of DKA at the time of diagnosis into mild, moderate, and severe according to the 2009 consensus statement of the American Diabetes Association [7] as follows: mild DKA, $\mathrm{pH}>7.25$ and $\mathrm{HCO}_{3} \geq 15 \mathrm{mmol} / \mathrm{L}$ or anion gap >10; moderate DKA, $\mathrm{pH} 7.0-7.24$ and $\mathrm{HCO}_{3} 10-15 \mathrm{mmol} / \mathrm{L}$ or anion gap $>12$; severe DKA, $\mathrm{pH}<7.0$ and $\mathrm{HCO}_{3}<10 \mathrm{mmol} / \mathrm{L}$ or anion gap $>12$. Serum $\mathrm{BHB}$, venous $\mathrm{pH}$, and electrolytes were followed up every $4 \mathrm{~h}$ until DKA was resolved. Resolution of DKA was defined as plasma glucose $<200 \mathrm{mg} / \mathrm{dL}$ plus any two of bicarbonate $\geq 15 \mathrm{mmol} / \mathrm{L}, \mathrm{pH}>7.3$, and anion gap $\leq$ $12 \mathrm{mmol} / \mathrm{L}$. Patients were excluded if they were unable to provide informed consent or had wide gap metabolic acidosis from other conditions (eGFR $<60 \mathrm{~mL} / \mathrm{min} / 1.73$ $\mathrm{m}^{2}$ ), drug-induced acidosis, chronic alcohol drinking, pregnancy, and serum lactate $>18 \mathrm{mg} / \mathrm{dL}(2 \mathrm{mmol} / \mathrm{L})$ [12].

\section{Biochemical measurements}

Serum BHB was measured by an enzymatic method, the Ranbut assay, obtained from Randox Laboratories Limited (United Kingdom). The test was linear for serum $\mathrm{BHB}$ at $0.1-5.75 \mathrm{mmol} / \mathrm{L}$ and had a correlation coefficient of $r=0.9954$. Serum glucose, blood urea nitrogen (BUN), creatinine, serum lactate, and serum electrolytes were measured using a Cobas 6000 analyzer series (c501 module).

\section{Ethical considerations}

This study was approved by the medical ethics committee of Maharaj Nakhon Si Thammarat Hospital, and the written informed consent was obtained from all participants according to the guidelines of Declaration of Helsinki. All methods in this study were performed in accordance with the relevant guidelines and regulations.

\section{Statistical analysis}

STATA $^{\circ}$ version 14 software was used for the statistical analyses. Descriptive statistics were measured by the patient number, percentage, or mean (min-max) as appropriate. Correlations between $\mathrm{BHB}$ and $\mathrm{pH}$, bicarbonate, and anion gap were established by Pearson correlation analysis. Values of $p<0.05$ were considered to indicate statistical significance. Serum BHB according to DKA severity was reported in median and interquartile range. Wilcoxon rank-sum test to assess the statistical difference in the median. 


\section{Results}

Between 01 October 2018 and 30 September 2020, 99 adult patients with diabetes mellitus were diagnosed with DKA at Maharaj Nakhon Si Thammarat Hospital, Thailand. The mean age was 39.4 years (range, 18-85 years). Most of the patients were female (63.4\%). The proportions of DKA predominant in type2 diabetes (53.6\%). While infections were the most common precipitating factor for DKA in T2DM (43.4\%), noncompliance with treatment was the most common precipitating factor of DKA in T1DM (43.5\%). Diabetes was first diagnosis in DKA episode was 17.2\% (T1DM 17.4\%, T2DM17\%). Treatment diabetes before DKA episode mostly used insulin 58.6\% (T1DM 82.6, T2DM 37.7\%). More than half of the patients were considered to have severe DKA (T1DM 67.4\%, T2DM 41.5), 27.3\% had moderate DKA (T1DM19.6\%, T2DM34\%), and 19.2\% had mild DKA (T1DM13\%, T2DM24.5\%). Serum glucose ranged from 250 to $1243 \mathrm{mg} / \mathrm{dL}$, with a mean of $490 \mathrm{mg} / \mathrm{dL}$. Level of glycated hemoglobin was $12.4 \%$ (range, 8.3-17.5\%). Effective serum osmolarity was 291 $\mathrm{mOsm} / \mathrm{Kg}$ (range, $252-360 \mathrm{mOsm} / \mathrm{kg}$ ). All DKA patients with high effective serum osmolarity more than $320 \mathrm{mOs} / \mathrm{kg}$ were T2DM (11.3\%). All patients were acidotic and the mean serum BHB was $5.9 \mathrm{mmol} / \mathrm{L}$ (range, $3.0-10.6 \mathrm{mmol} / \mathrm{L}$ ). The other details of baseline characteristics and laboratory data are shown in Table 1. Patients with type 2 diabetes were older, higher BMI, longer duration of diabetes, presented DKA combined with hyperosmolarity and had higher serum $\mathrm{pH}$, lactate, and $\mathrm{HCO}_{3}$, while patients with type 1 diabetes more commonly had severe DKA and hypokalemia after treatment.

The relationships among biochemical parameters during treatment of DKA were investigated. For type 1 diabetes patients (Fig. 1), there were negative correlations between serum $\mathrm{BHB}$ and $\mathrm{HCO}_{3}{ }^{-}(-0.6453)$, serum $\mathrm{BHB}$ and $\mathrm{pH}(-0.6015)$, and positive correlations between serum BHB and anion gap (0.8468), serum $\mathrm{HCO}_{3}{ }^{-}$and $\mathrm{pH}$ (0.7581). Likewise, in type 2 diabetes patients (Fig. 2), there were negative correlations between serum $\mathrm{BHB}$ and $\mathrm{HCO}_{3}^{-}(-0.6449)$, serum $\mathrm{BHB}$ and $\mathrm{pH}(-0.6207)$ and positive correlations between serum BHB and anion gap (0.8461), serum $\mathrm{HCO}_{3}{ }^{-}$and $\mathrm{pH}$ (0.7107). All of the corresponding correlations appeared comparable between the type 1 and type 2 diabetes patients.

Regarding the severity of DKA, the median serum BHB levels increased with increasing DKA severity. In all patients, the median serum BHB levels were 4.5 $\mathrm{mmol} / \mathrm{L}$ (IQR, 3.9-5.8) for mild DKA, $5.7 \mathrm{mmol} / \mathrm{L}$ (IQR, 4.7-6.7) for moderate DKA, and $5.9 \mathrm{mmol} / \mathrm{L}$ (IQR, 5.37.4) for severe DKA. In each severity category, there was no significant difference in the serum BHB levels between the patients with type 1 or type 2 diabetes (Table 2).

When DKA has resolved, BHB level is only 0.75 $\mathrm{mmol} / \mathrm{L}(0.6-0.9, p<0.01)$. The BHB level corresponding to the $\mathrm{HCO}_{3}$ criteria was $1.05 \mathrm{mmol} / \mathrm{L}(0.22-1.8$, $p=0.013$ ). However, BHB levels was not correlate to blood $\mathrm{pH}$. Sensitivity and specificity of BHB cut-of values for the determination of the resolution of DKA are shown in Table 3.

Median time to DKA resolution, as defined by $\mathrm{BHB}<$ $1 \mathrm{mmol} / \mathrm{L}$, serum $\mathrm{HCO}_{3}{ }^{-} \geq 15 \mathrm{mmol} / \mathrm{L}$ and anion gap $\leq$ $12 \mathrm{mmol} / \mathrm{L}$ was $12 \mathrm{~h}$. Not unexpectedly, $\mathrm{pH}>7.3 \mathrm{ap}-$ peared to be the main determinant of shorter resolution time. In subject with $\mathrm{pH}>7.3$, median time to resolution of DKA in type 2 diabetes was shorter than those with type 1 diabetes patients (Table 4 ).

\section{Discussion}

DKA can occur in both type 1 and type 2 diabetes patients, although the incidence was reported to be much higher in patients with type 1 diabetes in a Caucasian population $[3,4,16]$. In the present study, we found that the DKA occurred frequently in patients with type 2 diabetes, which is similar to previous studies in Asian populations $[5,6]$. This may be partly due to the very low prevalence type 1 with DKA in Thailand [17] as well as other countries in the tropics $[18,19]$ although ethnic or genetic variations in Asian patients with type 2 diabetes which might make them more prone to develop DKA cannot be ruled out [20]. In western countries, during the last two decades, hospitalizations for DKA at least in England have increased for both adult patients with type 1 diabetes and adult patients with type 2 diabetes [21].

In the present study, the initial laboratory evaluation of type 1 and type 2 patients including plasma glucose, glycated hemoglobin, blood urea nitrogen, creatinine, electrolyte, osmolarity, thyroid function test and serum BHB did not significant differ. Our results showed that precipitating factors for DKA are different in type 1 and type 2 diabetes. In our type 1 patients, discontinuation of treatments was the most common cause for the development of DKA while infection was a major precipitating factor in type 2 diabetes. With regard to mortality although the patients with type1 diabetes with DKA in our study had higher severity of the disease and more hypokalemia during treatment, there was no significant difference in mortality between DKA patients who had type 1 or type 2 diabetes, probably because of our study populations were younger than previous studies $[3,4]$ and a less severe disease because of the exclusion of other causes of acidosis To our knowledge, no investigations have examined the influence of type of diabetes on the relationship between DKA severity using common assessment methods and DKA outcomes. The present 
Table 1 Clinical characteristics of the study population $(N=99)$

\begin{tabular}{|c|c|c|c|c|}
\hline & All patients & Type 1 diabetes & Type 2 diabetes & $p$-value \\
\hline Patients, $n(\%)$ & $99(100)$ & $46(46.4)$ & $53(53.6)$ & \\
\hline Age (y), mean (min-max) & $39.4(18-85)$ & $26.5(18-47)$ & $50.5(20-85)$ & $<0.001$ \\
\hline Male sex, $n(\%)$ & $36(36.6)$ & $18(39.1)$ & $18(33.9)$ & 0.59 \\
\hline BMI $\left(\mathrm{kg} / \mathrm{m}^{2}\right)^{\mathrm{a}}$, mean (min-max) & $20(14.2-46.8)$ & $19.9(14.2-27.7)$ & $22.0(14.8-46.9)$ & 0.002 \\
\hline Duration of diabetes (year) & $6.3(0-25)$ & $4.8(0-15.3)$ & $7.5(0-25)$ & 0.02 \\
\hline \multicolumn{5}{|l|}{ Precipitating factor, $n$ (\%) } \\
\hline Non-compliance with treatment & $32(32.3)$ & $20(43.5)$ & 12(22.6) & \multirow[t]{5}{*}{0.118} \\
\hline Infections & $37(37.3)$ & 14(30.4) & $23(43.4)$ & \\
\hline Newly diagnosed & $17(17.2)$ & $8(17.4)$ & $9(17.0)$ & \\
\hline Other major stresses & $7(7.1)$ & $1(2.2)$ & $6(11.3)$ & \\
\hline No cause identified & $6(6.1)$ & $3(6.5)$ & $3(5.7)$ & \\
\hline \multicolumn{5}{|c|}{ Glucose-lowering drug $n(\%)$ : some patients received more than one drug } \\
\hline Metformin & $46(46.5)$ & $7(15.2)$ & 39(73.6) & $<0.001$ \\
\hline Sulfonylurea & $31(31.3)$ & $0(0)$ & $31(58.5)$ & $<0.001$ \\
\hline Thiazolidinedione & 11(11.1) & $2(4.4)$ & $9(17)$ & 0.05 \\
\hline Insulin & $58(58.6)$ & 38(82.6) & $20(37.7)$ & $<0.001$ \\
\hline \multicolumn{5}{|l|}{ Severity of DKA, $n(\%)$} \\
\hline Mild & $19(19.2)$ & $6(13.0)$ & $13(24.5)$ & \multirow[t]{3}{*}{$<0.05$} \\
\hline Moderate & $27(27.3)$ & $9(19.6)$ & $18(34.0)$ & \\
\hline Severe & $53(53.5)$ & $31(67.4)$ & $22(41.5)$ & \\
\hline \multicolumn{5}{|l|}{ Initial laboratory findings, mean (min-max) } \\
\hline Plasma glucose (mg/dL) & $490(250-1243)$ & $486(138-1088)$ & $494(241-1243)$ & 0.83 \\
\hline Glycated hemoglobin (\%) & $12.4(8.3-17.5)$ & $12.3(8.3-17.5)$ & $12.4(8.7-15.8)$ & 0.83 \\
\hline Serum BUN (mg/dL) & $19.9(5-71)$ & $19.3(7-48)$ & $20.5(5-71)$ & 0.60 \\
\hline Serum creatinine (mg/dL) & $0.75(0.27-1.46)$ & $0.75(0.27-1.41)$ & $0.74(0.35-1.46)$ & 0.83 \\
\hline eGFR (CKD-EPI, mL/min/1.73m²) & $107(60-194)$ & $119(62-194)$ & $98.5(60-144)$ & 0.001 \\
\hline Effective serum osmolarity $(\mathrm{mOsm} / \mathrm{kg})^{\mathrm{b}}$ & $291(252-360)$ & $289(251-316)$ & $293(252-360)$ & 0.21 \\
\hline Effective serum osmolarity $>320 \mathrm{mOsm} / \mathrm{kg}^{\mathrm{b}} \mathrm{n}(\%)$ & $6(6.1)$ & $0(0)$ & $6(11.3 \%)$ & 0.02 \\
\hline Free T4 $(\mathrm{ng} / \mathrm{dL})($ normal range $=0.93-1.71)$ & $1.2(0.8-4.1)$ & $1.2(0.8-4.1)$ & $1.2(0.8-1.9)$ & 0.27 \\
\hline TSH (mIU/L) (normal range = 0.27-4.2) & 1.8(0.05-13.2) & $1.9(0.05-13.2)$ & $1.9(0.35-5.0)$ & 0.91 \\
\hline Serum $\mathrm{Na}^{+}(\mathrm{mmol} / \mathrm{L})$ & $132(115-158)$ & $131(115-146)$ & $133(117-158)$ & 0.19 \\
\hline Corrected serum $\mathrm{Na}^{+}(\mathrm{mmol} / \mathrm{L})^{c}$ & $138(120-169)$ & $137(122-151)$ & 139(120-169) & 0.17 \\
\hline Serum $\mathrm{K}^{+}(\mathrm{mmol} / \mathrm{L})$ & $4.4(2.4-7.5)$ & $4.5(2.4-7.5)$ & $4.3(2.4-6.6)$ & 0.35 \\
\hline Serum $\mathrm{Cl}^{-}(\mathrm{mmol} / \mathrm{L})$ & $96(73-127)$ & $95(74-113)$ & $96(73-127)$ & 0.59 \\
\hline Serum $\mathrm{HCO}_{3}^{-}(\mathrm{mmol} / \mathrm{L})$ & $9.6(2.0-23.5)$ & $8.4(2.0-18.2)$ & $10.7(3.0-23.5)$ & 0.02 \\
\hline Anion gap $(\mathrm{mmol} / \mathrm{L})^{\mathrm{d}}$ & $26.6(12.5-42.8)$ & $27.4(14.4-42.8)$ & $25.9(12.5-41.7)$ & 0.24 \\
\hline $\mathrm{pH}$ & $7.18(6.68-7.42)$ & $7.14(6.70-7.41)$ & $7.21(6.68-7.42)$ & 0.02 \\
\hline $\mathrm{BHB}(\mathrm{mmol} / \mathrm{L})$ & $5.9(3.0-10.6)$ & $6.0(3.4-9.0)$ & $5.8(3.0-10.6)$ & 0.55 \\
\hline Lactate (mg/dl) & $11.7(4.9-18.0)$ & $10.7(4.9-18.0)$ & $12.6(5.6-18.0)$ & 0.01 \\
\hline Time to DKA resolution (h), mean (min-max) & $20.4(8-64)$ & $22(8-64)$ & $19.1(8-60)$ & 0.17 \\
\hline Complications during DKA treatment, $n(\%)$, events & $50(50.5), 59$ & $21(45.6), 25$ & $29(54.7), 34$ & 0.81 \\
\hline Hypoglycemia (blood sugar < 70 mg/dL) & $4(4.04)$ & $1(2.2)$ & $3(5.7)$ & 0.77 \\
\hline Hypokalemia $\left(\mathrm{K}^{+}<3.5 \mathrm{mmol} / \mathrm{L}\right)$ & $44(44.4)$ & $21(45.7)$ & $23(43.4)$ & 0.05 \\
\hline Hypernatremia $\left(\mathrm{Na}^{+}>145 \mathrm{mmol} / \mathrm{L}\right)$ & $11(11.1)$ & $3(6.5)$ & $8(15.1)$ & 0.83 \\
\hline Mortality & $0(0)$ & $0(0)$ & $0(0)$ & $0(0)$ \\
\hline \multicolumn{5}{|l|}{ Complications at time of DKA resolution, $n(\%)$} \\
\hline Hypokalemia ( $\left.\mathrm{K}^{+}<3.5 \mathrm{mmol} / \mathrm{L}\right)$ & $34(34.3 \%)$ & $17(37.0 \%)$ & $17(32.1 \%)$ & 0.26 \\
\hline Hyponatremia $\left(\mathrm{Na}^{+}<135 \mathrm{mmol} / \mathrm{L}\right)$ & $24(24.2 \%)$ & $12(26.1 \%)$ & $12(22.6 \%)$ & 0.16 \\
\hline Hypernatremia $\left(\mathrm{Na}^{+}>145 \mathrm{mmol} / \mathrm{L}\right)$ & $10(10.1 \%)$ & $2(4.4 \%)$ & $8(15.1 \%)$ & 0.13 \\
\hline
\end{tabular}

${ }^{a}$ The body-mass index is weight in kilograms divided by the square of height in meters

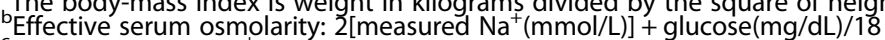

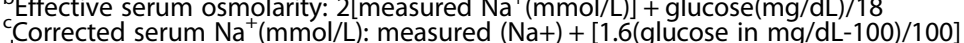

${ }^{c}$ Corrected serum $\mathrm{Na}^{+}(\mathrm{mmol} / \mathrm{L}):$ meas
${ }^{d}$ Anion gap: $\left(\mathrm{Na}^{+}\right)-\left[\left(\mathrm{Cl}^{-}+\mathrm{HCO}_{3}^{-}\right]\right.$ 

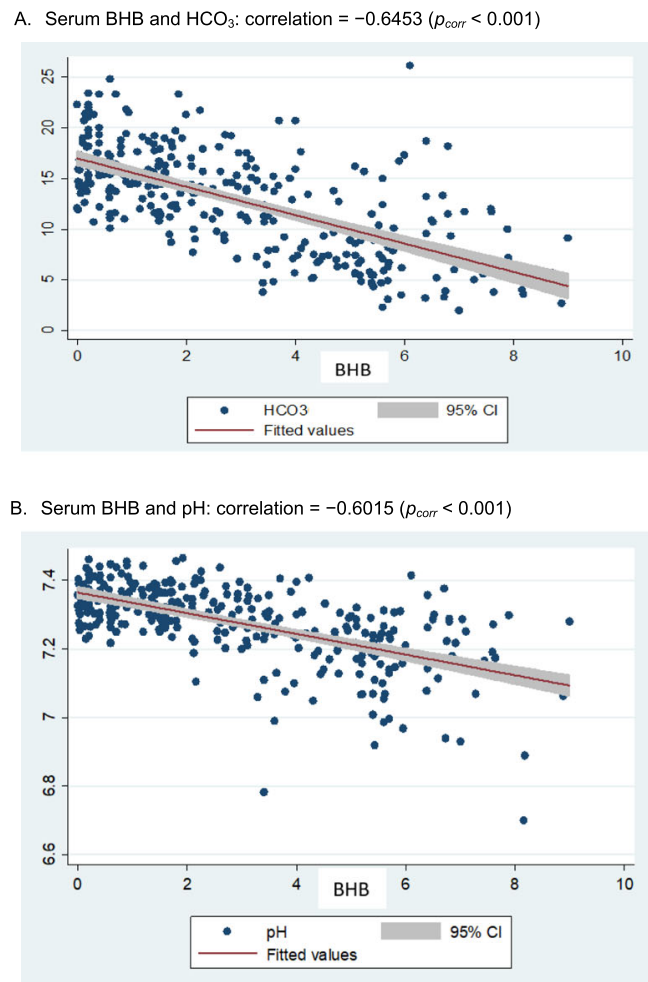

C. Serum BHB and anion gap: correlation $=0.8468\left(p_{\text {corr }}<0.001\right)$

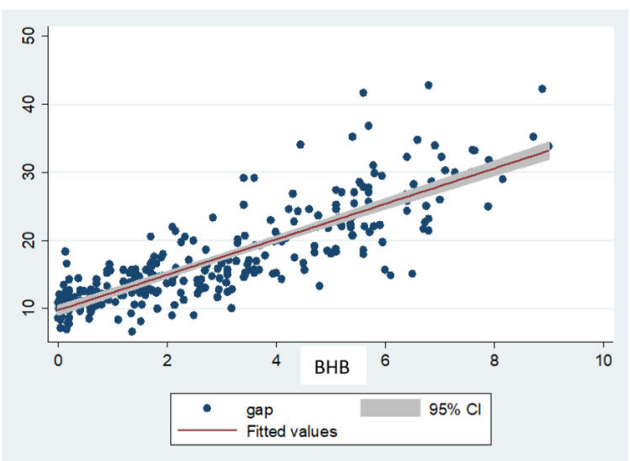

D. Serum $\mathrm{HCO}_{3}$ and $\mathrm{pH}$ : correlation $=0.7581\left(p_{\text {corr }}<0.001\right)$

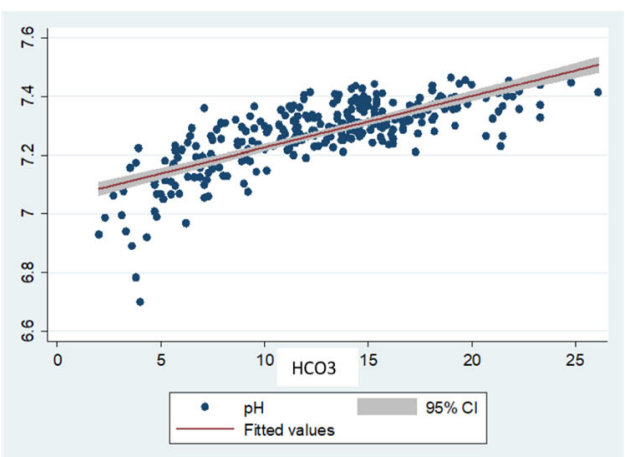

Fig. 1 Correlations between serum BHB and bicarbonate (A), serum $\mathrm{BHB}$ and $\mathrm{pH}(\mathbf{B})$, serum $\mathrm{BHB}$ and anion gap $(\mathbf{C})$, and serum bicarbonate and $\mathrm{pH}(\mathbf{D})$ in type 1 diabetes patients with DKA during treatment. $\mathbf{A}$ Serum $\mathrm{BHB}$ and $\mathrm{HCO}_{3}$ : correlation $=-0.6453$ ( $p_{\text {corr }}<$ 0.001), B Serum BHB and pH: correlation $=-0.6015$ ( $\left.p_{\text {corr }}<0.001\right)$. C Serum BHB and anion gap: correlation $=0.8468\left(p_{\text {corr }}<0.001\right)$. D Serum $\mathrm{HCO}_{3}$ and $\mathrm{pH}$ : correlation $=0.7581\left(p_{\text {corr }}<0.001\right)$

findings suggest that DKA should be assessed and treated similarly, regardless of its occurrence in type 1 or type 2 diabetes patients.

The findings of the present study demonstrate that the changes in serum BHB during treatment of DKA are significantly correlated with the changes in serum bicarbonate, serum anion gap, and venous $\mathrm{pH}$, and are consistent with the findings from a number of previous studies. A retrospective study reported a negative correlation between serum BHB and bicarbonate $(r=-0.64$; $p<0.001)$ [13]. Similarly, a prospective study demonstrated a negative correlation between serum BHB and bicarbonate $(r=-0.69)$ as well as a positive correlation between serum BHB and anion gap $(r=0.75)$ [14]. Negative correlations between serum $\mathrm{BHB}$ and $\mathrm{pH}(r=-$ $0.67)$ and serum BHB and bicarbonate $(r=-0.7)$ have also been reported [15]. With regard to capillary BHB, it was analyzed in a study on type 1 diabetes patients who developed DKA [22]. The study found correlations between capillary BHB and $\mathrm{pH}(r=-0.56419 ; p<0.0001)$ and capillary BHB and bicarbonate $(r=-0.24139 ; p=$ 0.0161 ). In the present study, the relationships between serum BHB and relevant parameters for monitoring of DKA did not differ significantly between type 1 and type 2 diabetes patients. These findings suggest that serum $\mathrm{BHB}$ can be used as a parameter for monitoring clinical symptoms in patients during DKA regardless of the type of diabetes. It should be noted that serum BHB provides better accuracy for assessment of DKA than capillary blood BHB [22], and the utilization of capillary blood $\mathrm{BHB}$ in this regard is unclear.

In the present study, we found upward trends for serum BHB with increasing severity of DKA that were similar between type 1 and type 2 diabetes patients. Our trends for serum BHB are consistent with findings for patients with type 2 diabetes [15] and children and adults with uncontrolled diabetes [23]. The former study found that the serum BHB levels corresponding to serum bicarbonate levels of 18,15 , and $10 \mathrm{mmol} / \mathrm{L}$ were $3.0 \mathrm{mmol} / \mathrm{L}$ for mild DKA, $4.7 \mathrm{mmol} / \mathrm{L}$ for moderate DKA, and $7.5 \mathrm{mmol} / \mathrm{L}$ for severe DKA. The latter study found the same trends that the serum BHB levels corresponding to serum bicarbonate levels of 18,15 , and 10 $\mathrm{mmol} / \mathrm{L}$ were $3.8,5.1$, and $8.9 \mathrm{mmol} / \mathrm{L}$, respectively. A study from the Joint British Diabetes Society in 2011 found that presence of capillary BHB $>6 \mathrm{mmol} / \mathrm{L}$ 


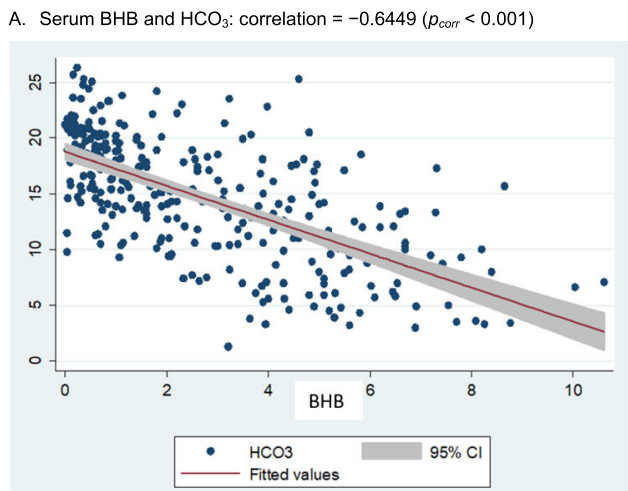

B. Serum BHB and $\mathrm{pH}$ : correlation $=-0.6207\left(p_{\text {corr }}<0.001\right)$

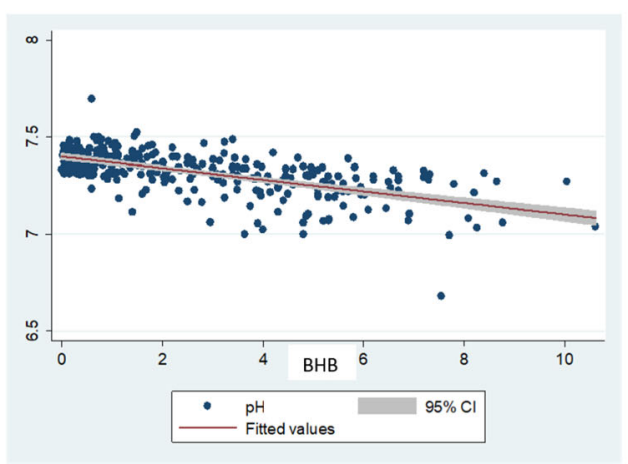

C. Serum BHB and anion gap: correlation $=0.8461\left(p_{\text {corr }}<0.001\right)$

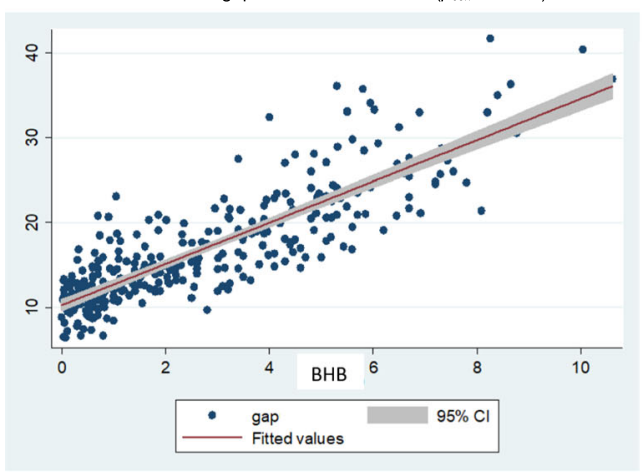

D. Serum $\mathrm{HCO}_{3}$ and pH: correlation $=0.7107\left(p_{\text {corr }}<0.001\right)$

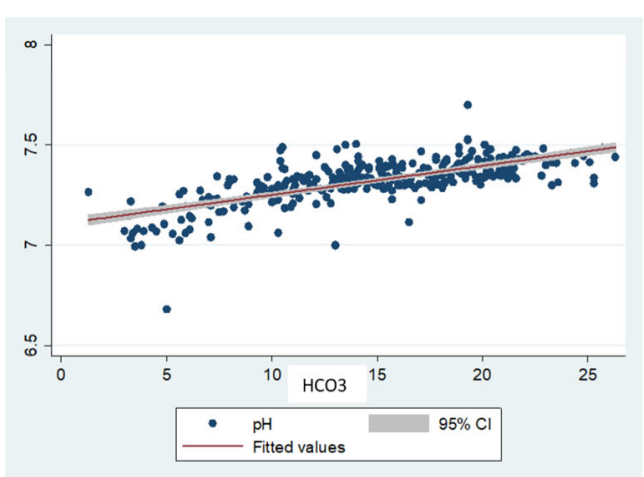

Fig. 2 Correlations between serum $B H B$ and bicarbonate (A), serum $\mathrm{BHB}$ and $\mathrm{pH}(\mathbf{B})$, serum $\mathrm{BHB}$ and anion gap $(\mathbf{C})$, and serum bicarbonate and $\mathrm{pH}(\mathbf{D})$ in type 2 diabetes patients with DKA during treatment. A Serum $\mathrm{BHB}$ and $\mathrm{HCO}_{3}$ : correlation $=-0.6449$ ( $p_{\text {corr }}<$ 0.001). B Serum BHB and pH: correlation $=-0.6207$ ( $\left.p_{\text {corr }}<0.001\right)$. C Serum BHB and anion gap: correlation $=0.8461\left(p_{\text {corr }}<0.001\right)$. D Serum $\mathrm{HCO}_{3}$ and $\mathrm{pH}$ : correlation $=0.7107\left(p_{\text {corr }}<0.001\right)$

indicated severe DKA [11]. Based on our data and the results from previous studies, we suggest that serum BHB levels can be categorized into $<5 \mathrm{mmol} / \mathrm{L}$ for mild DKA, 5-6 mmol/L for moderate DKA, and $>6 \mathrm{mmol} / \mathrm{L}$ for severe DKA, and should be similar in patients with type 1 and type 2 diabetes.

In the present study, BHB levels were not only associated with the severity of DKA but also related to the resolution of DKA as assessed by other biochemical parameters. Previous studies [11, 24, 25] have suggested that a BHB cut-off value of $0.6-1.5 \mathrm{mmol} / \mathrm{L}$ provided as definitions for DKA resolution. We found that $\mathrm{BHB}$ level $<1 \mathrm{mmol} / \mathrm{L}$ and any two of the following parameters including bicarbonate $\geq 15$ $\mathrm{mmol} / \mathrm{L}, \mathrm{pH}>7.3$ and anion gap $\leq 12$, BHB has acceptable sensitivity and good specificity for the resolution of DKA. The upward trend of $\mathrm{BHB}$ and serum $\mathrm{HCO}_{3}{ }^{-}$were from the volume depletion on admission [26]. In our study, median time to resolution of DKA defines by $\mathrm{pH}>7.3$ and a composite of $\mathrm{pH}>7.3$ and serum $\mathrm{HCO}_{3}{ }^{-} \geq 15 \mathrm{mmol} / \mathrm{L}$ was the shortest which may be due to the fact that $\mathrm{pH}$ is more sensitive to rapid changes in respiratory status. It is of note that the median time to DKA resolution in type2 diabetes was significantly shorter than in type 1 diabetes patients, which may be that in our study, patients with type 1 diabetes had more severe DKA. Clinicians must use clinical judgment when interpreting acid-base disorder during DKA treatment. We have shown that resolution of DKA as defined by $\mathrm{BHB}<1 \mathrm{mmol} / \mathrm{L}$ can be reasonably predicted by a composite of serum $\mathrm{HCO}_{3}{ }^{-}>15 \mathrm{mmol} / \mathrm{L}$ and anion gap $\leq 12 \mathrm{mmol} / \mathrm{L}$ according to the ADA guidelines [7]. Therefore, serum BHB may be widely used as a parameter for monitoring and resolution clinical symptoms of patients

Table 2 Serum BHB levels according to type of DKA and grading severity of DKA

\begin{tabular}{llll}
\hline & Mild DKA $^{\text {a }}$ & Moderate DKA $^{\text {a }}$ & Severe DKA $^{\mathbf{a}}$ \\
\hline $\begin{array}{l}\text { Serum BHB in type 1 } \\
\text { diabetes patients } \\
\text { (mmol/L), median (IQR) }\end{array}$ & $4.7(4.0-5.9)$ & $5.5(4.9-7.0)$ & $5.7(5.4-7.0)$ \\
$\begin{array}{l}\text { Serum BHB in type 2 } \\
\text { diabetes patients } \\
\text { (mmol/L), median (IQR) }\end{array}$ & $4.5(3.9-5.0)$ & $5.7(4.6-6.7)$ & $6.3(5.2-7.7)$ \\
$\begin{array}{l}\text { serum BHB in all } \\
\text { diabetes patients } \\
\text { (mmol/L), median (IQR) }\end{array}$ & $4.5(3.9-5.8)$ & $5.7(4.7-6.7)$ & $5.9(5.3-7.4)$ \\
\hline
\end{tabular}

a Grading severity for DKA was taken from to the 2009 consensus statement of the American Diabetes Association 
Table 3 Resolution of DKA (from ADA criteria) and the correlation of serum $\mathrm{BHB}$ with $\mathrm{pH}$ and $\left[\mathrm{HCO}_{3}{ }^{-}\right]$

\begin{tabular}{|c|c|c|c|}
\hline & & Sensitivity & Specificity \\
\hline Blood sugar & $<200 \mathrm{mg} / \mathrm{dL}$ & & \\
\hline Arterial $\mathrm{pH}^{\mathrm{a}}$ & $>7.3$ & & \\
\hline $\begin{array}{l}\text { Serum bicarbonate (mmol/ } \\
\text { L) or }\left[\mathrm{HCO}_{3}{ }^{-}\right]^{\mathrm{a}}\end{array}$ & $\geq 15$ & & \\
\hline Anion gap $(\mathrm{mmol} / \mathrm{L})^{a}$ & $\leq 12$ & & \\
\hline $\mathrm{BHB}(\mathrm{mmol} / \mathrm{L})$ & $\begin{array}{l}0.75(0.62-0.90) \\
p<0.01\end{array}$ & $58.6 \%$ & $100 \%$ \\
\hline $\begin{array}{l}\text { BHB corresponding to } \\
{\left[\mathrm{HCO}_{3}^{-}\right](\mathrm{mmol} / \mathrm{L})}\end{array}$ & $\begin{array}{l}1.05(0.22-1.87) \\
p=0.013\end{array}$ & $73.7 \%$ & $100 \%$ \\
\hline $\begin{array}{l}\text { BHB corresponding to } \mathrm{pH} \\
(\mathrm{mmol} / \mathrm{L})\end{array}$ & $\begin{array}{l}4.56(-11.9-21.0), \\
p=0.58\end{array}$ & $100 \%$ & $76.7 \%$ \\
\hline
\end{tabular}

${ }^{\mathrm{a}}$ The resolution criteria for DKA from ADA2009

during DKA. It is also useful in differentiating DKA from other conditions presenting with wide gap metabolic acidosis i.e. sepsis and renal failure. More reliable laboratory measurements may assist in reducing time to recovery and costs of hospital stay.

Our study is limited by exclusively using the Ranbut assay for BHB testing and comparison with other generally applied tests was not performed. Moreover, a single BHB cutoff value was used in both type 1 and type 2 diabetes as

Table 4 Median hour to DKA resolution (IQR) by diabetes type

\begin{tabular}{|c|c|c|c|c|}
\hline \multirow[t]{2}{*}{ Variables } & \multicolumn{3}{|c|}{$\begin{array}{l}\text { Median time to DKA } \\
\text { resolution in hour (IQR: Q1 } \\
\text { to Q3) }\end{array}$} & \multirow{2}{*}{$\begin{array}{l}p \text {-value } \\
\text { (Wilcoxon } \\
\text { rank-sum } \\
\text { test) }\end{array}$} \\
\hline & $\begin{array}{l}\text { All } \\
\text { patients }\end{array}$ & $\begin{array}{l}\text { Type } 1 \\
\text { diabetes }\end{array}$ & $\begin{array}{l}\text { Type } 2 \\
\text { diabetes }\end{array}$ & \\
\hline $\mathrm{BHB}<1 \mathrm{mmol} / \mathrm{L}$ & $\begin{array}{l}12(8 \text { to } \\
16)\end{array}$ & $\begin{array}{l}12(8 \text { to } \\
20)\end{array}$ & $\begin{array}{l}12 \text { (8 to } \\
16)\end{array}$ & 0.14 \\
\hline $\begin{array}{l}\mathrm{BHB}<1 \mathrm{mmol} / \mathrm{L} \text { and } \mathrm{pH} \\
>7.3\end{array}$ & $\begin{array}{l}10(6 \\
\text { to16) }\end{array}$ & $\begin{array}{l}12(8 \text { to } \\
18)\end{array}$ & $\begin{array}{l}8(6 \text { to } \\
12)\end{array}$ & 0.06 \\
\hline $\begin{array}{l}\mathrm{BHB}<1 \mathrm{mmol} / \mathrm{L} \text { and } \\
\text { serum } \mathrm{HCO}_{3}{ }^{-} \geq 15 \mathrm{mmol} / \\
\mathrm{L}\end{array}$ & $\begin{array}{l}11(8 \\
\text { to16) }\end{array}$ & $\begin{array}{l}12(8 \text { to } \\
20)\end{array}$ & $\begin{array}{l}8(6 \text { to } \\
14)\end{array}$ & 0.42 \\
\hline $\begin{array}{l}\mathrm{BHB}<1 \mathrm{mmol} / \mathrm{L} \text { and } \\
\text { anion gap } \leq 12 \mathrm{mmol} / \mathrm{L}\end{array}$ & $\begin{array}{l}12(8 \text { to } \\
16)\end{array}$ & $\begin{array}{l}14(8 \text { to } \\
20)\end{array}$ & $\begin{array}{l}12(8 \text { to } \\
16)\end{array}$ & 0.25 \\
\hline $\mathrm{pH}>7.3$ & $\begin{array}{l}8(4 \text { to } \\
12)\end{array}$ & $\begin{array}{l}8(4 \text { to } \\
16)\end{array}$ & $\begin{array}{l}4(4 \text { to } \\
8)\end{array}$ & 0.04 \\
\hline $\begin{array}{l}\mathrm{pH}>7.3 \text { and serum } \\
\mathrm{HCO}_{3}^{-} \geq 15 \mathrm{mmol} / \mathrm{L}\end{array}$ & $\begin{array}{l}8(4 \text { to } \\
14)\end{array}$ & $\begin{array}{l}12(6 \text { to } \\
16)\end{array}$ & $\begin{array}{l}6(4 \text { to } \\
12)\end{array}$ & 0.05 \\
\hline $\begin{array}{l}\mathrm{pH}>7.3 \text { and anion gap } \leq \\
12 \mathrm{mmol} / \mathrm{L}\end{array}$ & $\begin{array}{l}10(6 \\
\text { to } 14)\end{array}$ & $\begin{array}{l}12(8 \text { to } \\
16)\end{array}$ & $\begin{array}{l}8(6 \text { to } \\
12)\end{array}$ & 0.01 \\
\hline $\begin{array}{l}\text { Serum } \mathrm{HCO}_{3}{ }^{-} \geq 15 \mathrm{mmol} / \\
\end{array}$ & $\begin{array}{l}12(4 \text { to } \\
16)\end{array}$ & $\begin{array}{l}12(8 \text { to } \\
20)\end{array}$ & $\begin{array}{l}8(4 \text { to } \\
16)\end{array}$ & 0.06 \\
\hline $\begin{array}{l}\text { Serum } \mathrm{HCO}_{3}{ }^{-} \geq 15 \mathrm{mmol} / \\
\mathrm{L} \text { and anion gap } \leq 12 \\
\mathrm{mmol} / \mathrm{L}\end{array}$ & $\begin{array}{l}12(8 \text { to } \\
16)\end{array}$ & $\begin{array}{l}14(8 \text { to } \\
18)\end{array}$ & $\begin{array}{l}10(6 \\
\text { to14) }\end{array}$ & 0.26 \\
\hline Anion gap $\leq 12 \mathrm{mmol} / \mathrm{L}$ & $\begin{array}{l}12(8 \text { to } \\
16)\end{array}$ & $\begin{array}{l}12(8 \text { to } \\
20)\end{array}$ & $\begin{array}{l}12(8 \text { to } \\
16)\end{array}$ & 0.27 \\
\hline
\end{tabular}

it is currently unclear if the threshold would be different in DKA patients with type 1 and type 2 diabetes.

\section{Abbreviations}

DKA: Diabetic ketoacidosis; $\mathrm{BHB}$ : Beta-hydroxybutyrate; $\mathrm{HCO}_{3}$ : Bicarbonate; SGLT2: Sodium glucose co-transporter type 2 (SGLT2)

\section{Authors' contributions}

A.C. was responsible for the implementation of the project. B.O. managed the project and provided guidance. L.C. performed the biochemical analysis. A.C. and B.O. contributed to the study design, conducted the statistical analyses and drafted the manuscript. All authors had full access to all of the data in the study and approved the final manuscript.

\section{Funding}

No funding was obtained for this study.

\section{Availability of data and materials}

The datasets used and analyzed during the current study are available from the corresponding author on reasonable request.

\section{Declarations}

\section{Ethics approval and consent to participate}

The ethical approval for this study was obtained by the Ethical Review Committee of Maharaj Nakhon Si Thammarat Hospital. Written informed consent was obtained from all participants before collection of data.

\section{Consent for publication}

Not applicable.

\section{Competing interests}

The authors declare that they have no competing interests.

\section{Author details}

${ }^{1}$ Endocrine and Metabolism Unit, Department of Medicine, Maharaj Nakhon Si Thammarat Hospital, Nakhon Si Thammarat 80000, Thailand. ${ }^{2}$ Division of Endocrinology and Metabolism, Department of Medicine, Faculty of Medicine, Ramathibodi Hospital, Mahidol University, Bangkok 10400, Thailand.

Received: 29 July 2021 Accepted: 10 December 2021

Published online: 06 January 2022

\section{References}

1. Graves EJ, Gillum BS. Detailed Diagnoses and Procedures, National Hospital Discharge Survey, 1995. Vital and Health Statistics. Series 13, Data from the National Health Survey, no. 130 (November). 1997:1-146.

2. Malone ML, Gennis V, Goodwin JS. Characteristics of diabetic ketoacidosis in older versus younger adults. J Am Geriatr Soc. 1992:40(11):1100-4.

3. Barski $\mathrm{L}$, et al. Comparison of diabetic ketoacidosis in patients with type-1 and type-2 diabetes mellitus. Am J Med Sci. 2013;345(4):326-30.

4. Newton CA, Raskin P. Diabetic ketoacidosis in type 1 and type 2 diabetes mellitus: clinical and biochemical differences. Arch Intern Med. 2004;164(17): 1925-31.

5. Tan H, Zhou Y, Yu Y. Characteristics of diabetic ketoacidosis in Chinese adults and adolescents -- a teaching hospital-based analysis. Diabetes Res Clin Pract. 2012;97(2):306-12.

6. Thewijtcharoen $Y$, et al. Clinical characteristics and outcomes of care in adult patients with diabetic ketoacidosis: a retrospective study from a tertiary diabetes center in Thailand. J Clin Transl Endocrinol. 2019;16:100188.

7. Kitabchi AE, et al. Hyperglycemic crises in adult patients with diabetes. Diabetes Care. 2009:32(7):1335-43.

8. Laffel L. Ketone bodies: a review of physiology, pathophysiology and application of monitoring to diabetes. Diabetes Metab Res Rev. 1999;15(6): $412-26$

9. Harris $\mathrm{S}$, et al. Near patient blood ketone measurements and their utility in predicting diabetic ketoacidosis. Diabet Med. 2005;22(2):221-4.

10. Tantiwong P, et al. Capillary blood beta-hydroxybutyrate measurement by reagent strip in diagnosing diabetic ketoacidosis. Clin Lab Sci. 2005;18(3): $139-44$. 
11. Savage MW, et al. Joint British Diabetes Societies guideline for the management of diabetic ketoacidosis. Diabet Med. 2011;28(5):508-15.

12. Levey $\mathrm{AS}$, et al. A new equation to estimate glomerular filtration rate. Ann Intern Med. 2009:150(9):604-12

13. Sheikh-Ali M, et al. Can serum beta-hydroxybutyrate be used to diagnose diabetic ketoacidosis? Diabetes Care. 2008;31(4):643-7.

14. Fulop $M$, et al. Serum beta-hydroxybutyrate measurement in patients with uncontrolled diabetes mellitus. Arch Intern Med. 1999;159(4):381-4.

15. Ke P, et al. Establishment of blood beta-hydroxybutyrate threshold for diagnosis of type 2 diabetes ketoacidosis. Nan Fang Yi Ke Da Xue Xue Bao. 2014;34(10):1507-10

16. Wang ZH, Kihl-Selstam E, Eriksson JW. Ketoacidosis occurs in both type 1 and type 2 diabetes--a population-based study from northern Sweden. Diabet Med. 2008;25(7):867-70.

17. Reutrakul S, Deerochanawong C. Diabetes in Thailand: status and policy. Curr Diab Rep. 2016;16(3):28.

18. Mobasseri $\mathrm{M}$, et al. Prevalence and incidence of type 1 diabetes in the world: a systematic review and meta-analysis. Health Promot Perspect. 2020; 10(2):98-115.

19. Pinto ME, Villena JE, Villena AE. Diabetic ketoacidosis in Peruvian patients with type 2 diabetes mellitus. Endocr Pract. 2008;14(4):442-6.

20. Balasubramanyam A, et al. New profiles of diabetic ketoacidosis: type 1 vs type 2 diabetes and the effect of ethnicity. Arch Intern Med. 1999;159(19): 2317-22.

21. Zhong WW, Juhaeri J, Mayer-Davis EJ. Trends in hospital admission for diabetic ketoacidosis in adults with type 1 and type 2 diabetes in England 1998-2013: a retrospective cohort study. Diabetes Care. 2018;41(9):1870-7.

22. Rodriguez-Merchan B, et al. Capillary beta-hydroxybutyrate determination for monitoring diabetic ketoacidosis. Endocrinol Nutr. 2011;58(7):347-52.

23. Voulgari $\mathrm{C}$, Tentolouris $\mathrm{N}$. The performance of a glucose-ketone meter in the diagnosis of diabetic ketoacidosis in patients with type 2 diabetes in the emergency room. Diabetes Technol Ther. 2010;12(7):529-35.

24. Ham MR, Okada P, White PC. Bedside ketone determination in diabetic children with hyperglycemia and ketosis in the acute care setting. Pediatr Diabetes. 2004;5(1):39-43

25. Wolfsdorf Jl, et al. ISPAD clinical practice consensus guidelines 2014 Diabetic ketoacidosis and hyperglycemic hyperosmolar state. Pediatr Diabetes. 2014;15 Suppl 20:154-79.

26. Adrogue $\mathrm{HJ}$, et al. Plasma acid-base patterns in diabetic ketoacidosis. N Engl J Med. 1982;307(26):1603-10.

\section{Publisher's Note}

Springer Nature remains neutral with regard to jurisdictional claims in published maps and institutional affiliations.

Ready to submit your research? Choose BMC and benefit from:

- fast, convenient online submission

- thorough peer review by experienced researchers in your field

- rapid publication on acceptance

- support for research data, including large and complex data types

- gold Open Access which fosters wider collaboration and increased citations

- maximum visibility for your research: over $100 \mathrm{M}$ website views per year

At $\mathrm{BMC}$, research is always in progress.

Learn more biomedcentral.com/submissions 